\title{
Risk, Reflexivity and Democracy
}

\author{
Mediating Expert Knowledge in the News ${ }^{1}$
}

\author{
LOUISE PHILLIPS
}

According to Beck's theory of risk society (for example, 1992), industrial modernization has created a range of risks that are unlimited in time and space and which have sources and consequences for which no one can be held to account. Since we have no means of identifying the objects of risk and safety (risks are 'unknowable'), nothing can be trusted and every aspect of life becomes a potential source of danger and hence a potential source of anxiety. As a result of the proliferation of risks, people are more dependent on expert scientific knowledge ('scientific rationality') often conveyed through the media. But at the same time, people's faith in science has diminished and scientific rationality is increasingly being challenged by 'social rationality' which is based on social evaluation. Risks are open to social definition and construction, and the mass media, together with the sciences, play key roles in these processes. The media are a central site for struggle between the different forms of rationality over the source and effects of risks and possible solutions.

In this article, I view the role of the media in the construction and contestation of risks in terms of discourse analysis. Translating Beck's theory into discourse analytical terms, the struggle which Beck describes between different knowledge-claims - between claims deriving from social rationality and scientific rationality and between claims deriving from private everyday life and mediated experience - can be seen as a struggle between discourses which represent different ways of understanding the 'environment' and 'risk' and construct different identities for speakers (such as, for example, 'expert', 'activist', 'citizen' or 'consumer'). Responsibility for risks and their solution is subject to discursive negotiation in the media and in consumption of the media by audiences. The media represent a main field of publicness in which discourses are not only reproduced but transformed and re-articulated through institutionalized production practices. Mediated publicness involves a radical restructuring of the public and private spheres partly through the joint articulation of public information discourses and discourses based on face-to-face interpersonal communication in everyday life (Bondebjerg 1996, Chouliaraki 1999, Fairclough 1995b, Phillips 1999a). The aim of this article is to explore the operation of the media as a site for the construction and contestation of expert knowledge about the environment through an empirical study of a particular case: a Danish news broadcast featuring a discussion between two "experts" who each present competing forms of expert knowledge and the reception of the news broadcast by audience members (based on 27 individual and group interviews). ${ }^{2}$ A central focus is the role of the contestation of expert knowledge in the media in key developments in late modernity involving new forms of politics and power configurations. In particular, the 
article explores the implications of the mediatization of culture and politics for the question of democracy. The analytical framework applied is a form of social constructionist discourse analysis which attempts to integrate an analysis of broader questions of social practice, politics and power with analysis of specific communication practices - in this case, the production and consumption of a media text. In the following, I will elaborate on key theoretical themes relating to central social and political developments, then sketch out the discourse analytical framework and finally present the empirical analysis.

\section{Reflexivity and the Media}

The social and political consequences of contestation via the media can be understood in terms of Beck's theory of reflexive modernization (for example, Beck 1994, 1997). Reflexive modernization involves two forms of reflexivity: the first is a form of self-confrontation of the modernization process itself - a "self-confrontation with the consequences of risk society which cannot (adequately) be addressed and overcome in the system of industrial society" (Beck 1996: 28); the second is a form of reflection about existing social arrangements by citizens who are alarmed by the multiple hazards that face individuals and societies in the risk society. This second form of reflexivity lies behind a new forms of politics, subpolitics, whereby agents outside the political or corporatist system engage in political deliberation and action on moral issues relating, for example, to ecology, the family, gender and ethnicity. While people have become disillusioned with, and disengaged from, traditional forms of politics, they have become increasingly involved in subpolitics. Beck argues that through engagement in subpolitics, citizens outside parliamentary politics have taken power politically, placing the above moral issues on the agenda in the face of the resistance of the established parties (see also Schrøder and Phillips). The conflict between truth-claims in the media generated outside the orthodox political system is central to subpolitics: it both represents a form of critical, reflective debate in itself and may work to promote further subpolitical activity by providing viewers with the necessary knowledge for informed critique of experts' arguments.

The value of Beck's theory as an account of contemporary society is limited by its failure fully to take into account the cultural dimension of processes of risk definition and contestation (Alexander 1996, Cottle 1998, Wynne 1996). According to Beck, it is the nature of risks themselves which determine how they are socially defined and acted upon. This perspective stands in contrast to the culturalist perspective - including discourse analysis - which stresses that risk definition is a function of how risks are constructed in meaning rather than being just a reflection of how risks 'really are' ${ }^{3}$ However, while Beck's approach is overly rationalistic and insufficiently culturalist, it can still, I think, be used as a starting point for empirical study focusing on the cultural dimension.

In the study presented in this article, the contestation of knowledge is viewed as a cultural activity involving the struggle over different discursive constructions of the environment. The focus is on how knowledge-claims are discursively constructed and contested in the media, how audiences deal with, and participate in, the contestation of knowledge and on the social and political implications of media and audience practices. The cultural field is viewed along the lines of discourse theory as a field of struggle for hegemony between competing discourses (including competing discourses on ecological risks) each constructing different understandings of the world (including the "environ- 
ment', 'risk' and 'political action') and different identities for the subject (for example, as citizen or consumer) (Anderson 1997, Hannigan 1995).

The emphasis on the role of the media in discursive conflict is based on the view, noted above, that the media have become the main form of publicness in contemporary western societies, radically restructuring the public and private spheres and creating a form of political life which is, to a large extent, mediated. We are dependent on mediated/non-local knowledge as we do not ourselves have access to distant events and abstract systems. By mixing public information discourses and discourses rooted in faceto-face interpersonal communication in everyday life, the media create confidence in expert knowledge (Hjarvard 1997). This discursive mix appeals to people both as citizens and as private consumers. Mediatized politics is based on a combination of mass mediated public information and participation in the consumption of images, objects and ideas (Silverstone 1994). This can be seen as a move towards democratization since the combination of public, institutional discourses and everyday discourses may involve a construction of risks partially in terms of social rationality rather than purely in terms of scientific rationality. Power relations between the different actors - journalists, politicians, scientific experts and the public - may be restructured as everyday experience may be recognised as an alternative source of knowledge or expertise and lay people may be positioned as types of expert (Hjarvard 1999). Conflict between different forms of 'expert' and 'lay' knowledge may represent an opening-up of the debate to different forms of rationality which may further critical reflection amongst the actors - scientific experts, activists, journalists and members of the viewing public. The presentation of competing knowledge-claims in different discourses leads to a relativizing of knowledge - including the acceptance of non-scientific knowledge - which may open up for discussion of change and different forms of social organisation.

On the other hand, the consumption of media images can be understood as an obstacle to the development of the media as a space for democratic politics. According to the perspective of Habermas, for example, the media do not live up to the ideal of a public sphere in which the state is called to account before the people and state policies are subjected to critique by an informed and rational public (for example, 1989, 1994). The public no longer participate as actors in critical debate but as mere consumers of the authorities' public displays of prestige, as in feudal times. Critics of this position argue, however, that it is based on a flawed understanding of the nature of publicness. Whereas Habermas' model builds on a conception of the public sphere as a space for direct, non-mediated communication between representatives of the state and the public, the alternative model proposed by critics (for example, Thompson 1995) posits a vision of democracy which is not dependent on face-to-face dialogue but on the mass mediated communication of knowledge which allows people to engage in informed, private deliberation. Habermas's negative view that discursive argumentation between competing perspectives has decreased has also been challenged. Eder (1996) claims, for instance, that a second transformation of the public sphere has taken place, involving the increasing use of the media by conflicting collective actors and the corresponding rise of public debate. Environmental discourse, he argues, is, at present, the most productive cultural form for producing and mobilising political conflict and consensus. It brings issues of collective rationality onto the agenda which are then defended against individual rationality in a political struggle to attribute responsibility.

In this article, I explore the democratic potiential of the contestation of knowledge in the media through empirical study of discursive practices in the media and in media reception. The focus is on how media and audience discourses construct different repre- 
sentations of environmental risk and different identities for actors and on the social and political implications of these discursive constructions. My approach to analysing discourse is outlined in the next section.

\section{Analytical Framework}

The discourse analytical framework which I apply is based on two forms of text-oriented discourse analysis: discursive psychology and the critical discourse analysis of Norman Fairclough (Fairclough 1992, 1995a, 1995b). Both critical discourse analysis and discursive psychology draw on Foucauldian discourse theory in conceiving discourse as (at least partly) constitutive of knowledge, identities and social relations but diverge from them in key respects. Drawing on discourse theory, my research framework follows a Foucault-inspired definition of discourse as a limited range of possible statements promoting a limited range of meanings so that discourses dictate what it is possible to say. But, drawing on both discursive psychology and CDA, I diverge from Foucauldian discourse theory in focusing empirically on everyday discursive practices in specific social contexts rather than focusing on discursive practices in more abstract terms. My empirical focus is on how struggles between discourses take place and discourses are reproduced and changed through communicative practices in everyday social interaction.

For the overall model of discourse as social practice and for a methodology for detailed discourse analysis, I apply Fairclough's critical discourse analysis. In critical discourse analysis, discourse is analysed in terms of three dimensions, discursive practice, text and social practice. The focus is on discursive practice - the ways in which discourses are articulated to produce and consume texts - text - the ways in which these discourses are realized linguistically in specific texts - and social practice - the wider social and cultural structures and processes which the discursive practices are shaped by and work to reproduce and change. Like Fairclough, I distinguish between discursive practices and the wider social practice, and I use social theory in order to cast light on the wider social practice in which discursive practice is a central force. But in contrast to Fairclough, I do not distinguish so sharply between the discursive and the non-discursive; my framework is not based on an ontological distinction between discourse and non-discourse but on an analytical distinction between the wider social practice - the background for analysis - and concrete discursive practice - the object of empirical analysis (Jørgensen og Phillips 1999). My position is that a sharp distinction between discourse and non-discourse entails an underestimation of the role of discourse in the social constitution of the world; it does not mean that I deny that there are material and other realities but rather that I stress that we give them meaning through discourse. I view social theory as providing understandings of the wider social practice, and, following from this, as cues for analysis of the discursive dimension of these social practices. By drawing on particular sociological perspectives on risk, reflexivity and democracy and by translating them into the terms of discourse analysis, the analytical framework constructs the research field in a particular way so that certain questions become relevant to ask (Jørgensen and Phillips, 1999; Phillips 2000).

While my analysis is structured according to Fairclough's three dimensions, I supplement them with a discursive psychological approach which places rather more weight on how discourses are used as flexible resources in talk-in-interaction. Like critical discourse analysis, discursive psychology focuses on the discursive construction 
of knowledge and identities and on language users as both products and active producers of discourse. But discursive psychologists place less weight on the linguistic construction of discourses and more weight on the rhetorical orientiation of discourse - on how people orient discourse towards forms of social action in specific contexts. I follow the approach of discursive psychologists, Wetherell and Potter (1992), which combines a poststructuralist, discourse-theoretical focus on the ways in which specific discourses constitute subjects and objects and an interactionist focus on the ways in which people's discourse is oriented towards social action in specific contexts of interaction. In viewing people as both the products of specific discourses and producers of talk in specific interactional contexts, the aim is to take account both of the constraints on action imposed by the use of specific discursive resources and of people's role as agents in processes of discursive reproduction and change (Phillips 2000) ${ }^{4}$. Media audiences use media discourses (as well as other discourses) as resources in interpretation so that the discourses constrain interpretation; but audiences do not merely reproduce media discourses but articulate them actively and selectively together with other discourses which circulate in society and are accessible to them. The focus of analysis of media and audience discourse is partly on the ways in which the accounts of environmental risks are constructed in order to appear as if they are true ('the epistemological orientation of accounts' in Potter's terms [1996]) and partly on the ways in which the accounts represent forms of social practice rather than just reflecting an external psychological or social reality ('the action orientation of accounts', Potter 1996).

In the following analysis, I explore a particular instance of struggle in the media between competing discourses about environmental risk in relation to wider questions of reflexivity and democracy. The texts analysed are a TV report and broadcast discussion on the 9 o'clock news on Danish public television on 4 February 1998 and reception of the news broadcast by audience members. The TV report announces the publication of a report by the environmentalist organisation World Watch Institute and introduces the discussion between Lester Brown, the leader of World Watch Institute and a supporter of radical environmental change, and Bjørn Lomborg who is a lecturer in the department of political science at Aarhus University in Denmark and has become a central figure in the Danish media as an opponent of radical change to the global environment. The discussion took place in English with Danish subtitles. The following analysis draws on earlier analysis which was carried out in Danish (Phillips 1999a, 1999b; Chouliaraki and Phillips 1999). Both in the Danish-language analysis and in the present analysis, I choose to concentrate on the subtitles and the interplay between the subtitles and the visuals on the basis of the assumption that they are the main source of meaning for the audiences. Thus, rather than analysing the English dialogue, I analyse an English translation of the Danish subtitles. At the same time, I take account of the links between the dialogue and the subtitles since it obviously plays a role that the dialogue was in English. I also focus on bodily forms of communication (for example, facial expressions and movements), as they contribute to constructing meaning.

\section{Media text: DR1 TV News, 21. 00, 4 February 1998}

Newsreader [in newsroom]: Verdensmiljøet har det ikke godt. Det hævder miljøorganisationen World Watch Institute i en ny rapport. Men det har organisationen faktisk hævdet hvert år i en menneskalder og nogle forskere er ved at blive godt trætte af dommedagsprofetierne. 
Reporter Jan Ewens' voice-over [shot of Lester Brown talking to two men in a corridor]: Lester Brown kom til Danmark i dag for at præsentere miljørapporten. Lester Brown har i årtier været miljøguruen over alle miljøguruer.

[close-up shot of report] Hans rapport om verdens tilstand er et anerkendt standardværk.

[shot of Lester Brown talking to camera] Lester Brown: Målet er at fremlægge oplysninger, der er nyttige for beslutningstagere.Vi har ikke en politisk dagsorden $\mathrm{i}$ ideologisk forstand. Vores mål er at beskrive hvad der sker med verden.

[shot of Lester Brown and Bjørn Lomborg on sofa but with Lester Brown still talking to camera] Lester Brown: Vi skal beskrive det, som det er. Hvis du går til lægen pga. højt blodtryk eller hudkræft og lægen siger, at alt er i orden [Lester Brown turns away from camera to face Bjørn Lomborg] ville du vel blive vred? [shot of Bjørn Lomborg smiling and nodding]

[shot of boy picking potatoes in a field] Voice-over: Lester Browns vigtigste budskab er at jorden ikke kan producere mad nok til en stigende befolkning.

[shot of corn being harvested] Voice-over: Produktionen af korn stiger men befolknings tilvæksten er større.

[shot of boy picking potatoes in a field] Voice-over: Det bliver værre år for år siger Lester Brown

[shot of hands flicking through report] Voice-over: Men i år skal Lester Brown ikke levere sin miljørapport uden sværdslag.

[close-up shot of Bjørn Lomborg talking to Lester Brown] Voice-over: En dansk forsker har gået Lester Browns statistik efter i sømmene og mener at den ikke holder vand.

[shot of Bjørn Lomborg and Lester Brown; BL talking] Bjørn Lomborg: Det virker, som om De tilbageholder kendsgerninger, der ikke passer med den almindelige pessimisme i rapporten.

[shot of Lester Brown and Bjørn Lomborg; LB talking] Lester Brown: Vores rapport skal ikke være pessimistisk men realistisk. Når vi siger, der var enorme skovbrande i Indonesien i fjor er det en kendsgerning. Vi bryder os måske ikke om det, men det er realiteten.[Bjørn Lomborg nods]

Bjørn Lomborg: Min pointe er, at De ofte, når De omtaler de negative ting, der sker, fortier andre ting. Hele bogen igennem siger De verden er på randen af sammenbrud. Og den slags prognoser er ikke til at have med at gøre. Man kan ikke se hvilke data, der underbygger dem eller ej, og det gør bogen mere ideologisk end Deres data giver belæg for.

Lester Brown: FAOs oplysninger viser at verdens kornproduktion pr. person fra 1950 til 1984 er vokset med 38\%, men siden er den faldet med 6\%.

Bjørn Lomborg: Men det er ikke relevant her for så ser man bort fra

Lester Brown: Hvis korn er ens vigtigste næringsmiddel er det relevant.

[BL laughs and bends over to pick up a piece of paper]

Bjørn Lomborg: [looking at/reading the paper] Men hvis man ser på FAO’s data for ulandene så stiger produktionen.

[shot of a forest where a crane is lifting a bundle of tree-trunks] Voice-over: Unenigheden gælder ikke kun kornproduktionen. De to forskere kan hellere ikke blive enige om, hvad der sker med verdens skove. 
[shot of LB and BL talking] Lester Brown: Det jeg ser underbygger FAO's data: Nemlig at verden mister skove i jævnt tempo. Man ser det i Amazonas og i Sydøstasien og i Indien. Jeg opholdt mig i indiske landsbyer i 1956. Dengang var meget af Indien dækket af skov, men i dag er skoven væk.

Bjørn Lomborg: Indien har faktisk øget sit skovareal i de seneste 10 år.

Lester Brown: Det er muligt, men i 1956 var der meget mere.

Bjørn Lomborg: De insisterer på at bruge oplysninger fra 50’erne. Men fra 1950 og fremefter har vi ifølge FAO fået mere skov globalt set.

Lester Brown: Ikke ud fra FAOs oplysninger. Vi må tjekke tallene i FAO’s årbog.

\section{[BL laughs]}

Bjørn Lomborg: Det har jeg gjort.

Lester Brown: Det har vi også [nodding].

Bjørn Lomborg: Skal vi vædde?

Newsreader [in newsroom]: Lester Brown ville dog ikke vædde om statistikken, men han sagde efter debatten, at det har været en fornøjelse at diskutere med en så venlig og velinformeret modstander.

\section{Translations of Danish Subtitles}

\section{Media text: DR1 TV News, 21. 00, 4 February 1998}

Newsreader [in the newsroom]: The world environment is not well. That's what the environmental organisation World Watch Institute claims in a new report. But the organisation has actually claimed this every year throughout a lifetime and some researchers are getting tired of these doomsday prophesies.

Reporter Jan Ewens' voice-over [shot of Lester Brown talking to two men in a corridor]: Lester Brown came to Denmark today to present the environmental report. Lester Brown has for years been the environmental guru of all environmental gurus.

[close-up shot of report]. His report about the state of the world is a recognised reference work. [shot of Lester Brown talking to camera] Lester Brown: The goal is to put forward information which is useful for decision-makers. We do not have a political agenda in an ideological sense.

[shot of Lester Brown and Bjørn Lomborg on sofa but with Lester Brown still talking to camera] Our goal is to describe what is happening with the world. We must describe it as it is. If you go to the doctor because of high blood pressure or skin cancer and the doctor says that everything is ok, [Lester Brown turns away from camera to face Bjørn Lomborg] wouldn't you get angry? [shot of Bjørn Lomborg smiling and nodding]

[shot of boy picking potatoes in a field] Voice-over: Lester Brown's most important message is that the earth cannot produce enough food for a growing population.

[shot of corn being harvested] Voice-over: The production of corn is increasing but the growth of the population is greater.

[shot of boy picking potatoes] Voice-over: It is getting worse year after year says Lester Brown. 
[shot of Worldwatch report] But this year Lester Brown is not going to deliver his report without a fight.

[close-up shot of Bjørn Lomborg talking to Lester Brown] A Danish researcher has turned Lester Brown's statistics inside out and thinks that they do not hold water.

[shot of Bjørn Lomborg and Lester Brown; Bl is talking] Bjørn Lomborg: It seems as if you are holding back facts, which do not fit the general pessimism of the report.

[shot of Bjørn Lomborg and Lester Brown; LB is talking] Lester Brown: our report must not be pessimistic but realistic. When we say there were huge forestfires in Indonesia last year, that is a fact. We maybe do not like it, but it's the reality.

[shot of Bjørn Lomborg nodding]

Bjørn Lomborg: My point is that they often when you talk about the negative things that happen, you keep quiet about other things. Throughout the whole book you say that the earth is on the verge of collapse. And those kinds of prognosis can't be worked with. One cannot see what kind of data they're based on or not, and that makes the book more ideological than your data gives support for.

Lester Brown: FAO's information shows that the world's corn production per person has risen from 1950 til 1984 by $38 \%$, but since then it has fallen by $6 \%$.

Bjфrn Lomborg: But that's not relevant here because one ignores

Lester Brown: If corn is one's most important form of nutrition then it is relevant.

[shot of Bjørn Lomborg laughing and bending over to pick up a piece of paper]

Bjørn Lomborg: [looking at the paper] But if you look at FAO's data for the third world, production is rising.

[shot of a forest, where a crane is lifting a bundle of tree trunks] Voice-over: The disagreement isn't just about the production of corn. The two researchers cannot agree either on what is happening with the world's forests.

Lester Brown: What I see backs up FAO's data: that is, that the earth is losing forests at a steady rate. One sees it in Amazonas and in Southeast Asia and in India. I stayed in Indian villages in 1956. Then much of India was covered in forest, but to day the forest is gone.

Bjorn Lomborg: India has actually increased its forested area in the last 10 years.

Lester Brown: That's possible, but in 1956, there was a lot more.

Bjørn Lomborg: You insist on using information from the 50's. But from 1950 onwards we have according to FAO got more forests in global terms.

Lester Brown: Not according to FAO information. We must check the figures in FAO's annual report.

[BL laughs]

Bjorn Lomborg: I have done that.

Lester Brown: So have we [nodding]

Bjфrn Lomborg: Shall we bet?

Newsreader[in newsroom]: Lester Brown did not want to bet about the statistics, but he said after the debate that it had been a pleasure to discuss with such a friendly and well-informed opponent. 


\section{Analysis}

Following the framework of Fairclough's critical discourse analysis, the analysis concentrates on three dimensions: discursive practice - the nature of the discourses and genres which the speakers articulate and the ways in which these discourses and genres construct knowledge, identities and social relations in ways that exclude and challenge alternatives; text - how discourses and genres are constructed through linguistic features such as grammar, transitivity, theme and modality and key words and phrases; and social practice - the ways in which discursive practices are part of, and work to reproduce and change, the wider social practice, by constituting representations of the world, social identities and social relations.

Throughout the TV broadcast, there is a struggle between two competing scientific discourses which struggle to fix meaning in their own ways: the environmentalist discourse of high risk (there is immediate danger as a result of the economic exploitation of nature) and an environmental discourse of low risk which questions the claim of high risk (there is no immediate danger as a result of economic activity). Each discourse has consequences for social action: according to the first discourse, it is crucial that one acts through intervention in industry; according to the second, such economic intervention is unnecessary. Both discursive constructions are introduced in the newsreader's and reporter's talk and drawn on further in the subsequent discussion between Lester Brown and Bjørn Lomborg. I will first analyse the newsreader's and reporter's introduction to the discussion before analysing the discussion itself.

\section{Newsreader's and Reporter's Introduction}

The newsreader and the reporter represent World Watch Institute's perspective as an environmentalist discourse of high risk. This discourse sees the earth as a natural resource and warns that the earth's productive capacities are insufficient given the rising world population. Environmental risk here is a question about the disparity in growth between natural resources and the world population. The discourse combines activist engagement (the agent is an important international grassroots organisation and encourages people to show concern) and critical pessimism (It is getting worse year after year). By being positioned as an agent in an existential process, the world environment is personified as suffering, a process usually attributed to humans (The world environment is not well). This situates the topic within an everyday life discourse rather than a scientific discourse. Throughout the newsreader's text, this construction of risk is reinforced by statements such as the earth cannot produce enough food for a growing population, the production of corn is growing but the population growth is greater and it is getting worse year after year. These categorical statements sustain the introductory construction of risk in projecting the earth as an agent which lacks the capacity to provide for its population. The earth's population are positioned not as agents but as mere receivers of the earth's food or as an attribute of growth whereby growth is nominalized. There is a shift to a more scientific discourse here (partly through nominalization), mixing lay and expert discourses. The environmentalist discourse of high risk places emphasis on risk by making the earth into an agent as the producer of resources and by warning against the limitations of the earth's productive capacities in the face of an ever-increasing world population.

Whereas the initial statement (the world environment is not well) is presented as an general statement rather than as reported speech, the second clause of the text (That's what the environmental organisation World Watch Institute claims in a new report.) at- 
tributes the statement to a source, the World Watch Institute and its report. Thus the statement is first presented as a 'fact' and then identified as somebody's viewpoint - a textual move which subverts the initial force of the statement (Chouliaraki and Phillips 1999).

In the second clause, the source of information is World Watch's new report while, in the rest of the broadcast, the source of information is described in other terms: (Lester Brown's report, Lester Brown's most important message, Lester Brown, Lester Brown says, his environmental report, Lester Brown's statistics). These terms function as an element of substitution for World Watch Institute and, consequently, the Institute's report systematically collocates with Lester Brown to create textual cohesion throughout the broadcast: the report is both the Institute's and, increasingly so as the text unfolds, Lester Brown's. This modification of meaning works in this text to personalize the report and perhaps deprive it of its institutional authority and collective nature: if the 'statistics' are attributed to Lester Brown only (as opposed to a group of scientific researchers) then the chances of 'his report' being proven wrong are higher. At the same time, however, the status of World Watch Institute's report as expert knowledge is reinforced through the labelling of the report as a recognised classic. The description of Brown himself as the environmental guru of all environmental gurus can also be understood as reinforcing this status. But, on the other hand, the terms guru and doomsday prophesies have connotations of religious extremism which challenge Brown's scientific credibility.

Lester Brown's critics are positioned more unambivalently as both experts and 'ordinary people'. Their description as some researchers endows them with scientific authority while the statement that they are getting tired of these doomsday prophesies gives them credibility as ordinary people who have feelings based on common-sense judgements rather than scientific knowledge alone. Thus they are ascribed identities both as experts and as ordinary people through their positioning within a mix of scientific discourse and everyday discourse, promoting identification between experts and audience. Identification is reinforced by the fact that they are not ascribed names, titles, or institutional affiliations - such labels would create specific expert identities and so create a sharp divide between lay people and experts (Chouliaraki and Phillips 1999). It may also be accomplished through Bjørn Lomborg being introduced as 'a Danish researcher' one of the Danish people - instead of his being introduced in terms of his academic position or relevant research interests.

Bjørn Lomborg's views are defined as an anti-discourse. It is an anti-discourse in that it does not put forward a developed independent vision of the environment but defines itself in terms of a relationship of opposition to the discourse of high risk. This is most clear in the formulation, But this year Lester Brown is not going to deliver his report without a fight. In addition, the discourse is a hybrid mix of scientific discourse and everyday lay discourse which positions speakers as both experts and lay people. For instance, in the statement, 'A Danish researcher has turned Lester Brown's statistics inside out and thinks that they do not hold water', the researcher is positioned in this dual way as the agent of two processes - a material one (has turned Lester Brown's statistics inside out and a mental one (thinks): while the second process, thinks, constructs the researcher as a 'senser', a rational, thinking being, the first process, has turned ..inside out, constructs the researcher partly as a 'senser' (the process involves cognition) and partly as a 'doer' actively involved in some material action (turning the statistics inside out). Positioning as both 'senser' and 'doer' may work to blur the expert-lay boundary. In addition, both 'turning statistics inside out' and 'thinking that they do not hold water' are both instances of everyday discourse which work to re-signify the scientific 
process of establishing validity in lay terms (contrast, for example, alternative descriptions of the processes such as 're-calculated the statistics' or 'judged them to be inaccurate'). Within the anti-discourse, expertise is cast almost entirely in lay terms, with only one element of scientific rationality - statistics - surviving re-signification (Chouliaraki and Phillips 1999).

The high risk discourse is firmly positioned as an institutional and expert discourse with particular and clear meanings on risk and the environmental condition. In contrast, the environmentalist anti-discourse is ambivalently positioned as both lay and expert, with no clear meanings on risk but with a clear representation of expertise itself: the scientific evaluation of expert knowledge is about how to calculate (statistics) and what kinds of meanings to assign to these calculations (the world environment is not well as opposed to doomesday prophesy). Thus the newsreader's and reporter's texts do not establish two discourses with equal authority claims, but rather one environmentalist discourse which constructs the environmental problematic from a particular point of view that of high risk - and the expert as a prestigious institutional agent and activist and another discourse which 'bypasses' the construction of the environmental condition and, instead, directly challenges the validity of the former in terms of its interpretation of the world and its scientific processing. I think, then, that the relations between the competing discourses and the positions assigned to the different speakers in the subsequent debate are partly established by the newsreader's and reporter's text in ways which subtly but consistently promote the anti-discourse at the expense of the authority of the high risk discourse.

\section{Debate between Lester Brown and Bjфrn Lomborg}

In the debate between Lester Brown and Bjørn Lomborg, the two discourses are articulated through combinations of scientific discourse and everyday, lay discourse. Both speakers construct their accounts in ways which challenge each other's alternative version of reality and give the impression that their own version is not in their own private interests but represents facts. Both discourses are constructed as solid and objective through rhetorical strategies such as the use of categorical modalities: within both discourses, claims are presented as clear and uncontrovertible facts. For example, Lester Brown states that FAO's information shows that the world's corn production per person has risen from 1950 til 1984 by 38\%, but since then it has fallen by 6\% rather than, for example, corn production may have risen from 1950 til 1984 ... but... may have fallen. And the claims are further presented as facts that exist independently of the individual speaker through the use of objective rather than subjective modalities - BL says, for example, It isn't relevant here instead of I don't think it's relevant here. Another rhetorical strategy is the use of figures to support the speaker's own version and challenge the other's use of figures. For example, BL implies that Browns use of figures from the 50's isn't legitimate: You insist on using information from the 50's.

While both discourses contain the above typical features of scientific discourse, they each represent different types of scientific discourse as pointed out earlier in discussion of the newsreader's and reporter's text. While the anti-discourse does not reject scientific knowledge - its challenge to the competing discourse is based on LB's failure to use scientific methods properly - it is based on a principle of epistemic doubt directed towards the truth claims of the high risk discourse. This principle of epistemic doubt may gain resonance amongst audiences as it may feed on people's loss of faith in scientific authority. 
As in the newsreader's and reporter's text, the two discourses combine scientific and everyday discourse in different ways in the discussion. Brown draws on a discourse of everyday life when he draws parallels between treatment of the environment and people's treatment by doctors. And at the end of the discussion, the participants switch from scientific discourses to an everyday discourse in which they challenge each other's use of figures: luck replaces scientific criteria for determining the truth: shall we bet? By using everyday discourse they draw on a conversational genre. This is articulated through language and humour (smiling etc). Conversational elements and humour also work rhetorically: BL constructs an identity as an ordinary person who is on the side of the people against the expert LB. LB has told his story over a lifetime, while BL has control over the present; he expresses a popular skepticism for scientific authority. He exudes what Fairclough calls an ethos of commonsense which is populist. This supports the anti-discourse which is based on epistemic doubt - a scepticism towards scientific claims. Other features that construct this ethos are his youth, his informal clothes, his reference to LB's use of old figures, and, perhaps, his Danishness. The discussion is thus partly a scientific discussion and partly a private conversation. By using the conversational-genre the discussion simulates a private conversation. The two men sit and talk on a sofa in a room instead of around a table in a studio. The audience become "voyeurs", observing a private conversation.

Above I have sketched out the discursive practice and illustrated ways in which the discourses of high and low risk and the conversational genre are articulated textually. Turning to the issue of social practice, I now focus on what kinds of insight the analysis of discursive practice provides into social practice, power and democratic politics. One can view the use of competing scientific discourses as a social practice which expresses and promotes a conflict between competing understandings of environmental risk and between different claims to expert status (each of the speakers threatens the other's identity as expert). This struggle can be understood as a reflection of, and a contribution to, broader social developments in risk society: different discourses struggle to define the truth. The public come to know that there is not one truth and one authority but several, and that people's claims to be experts can be questioned. This can be seen as an expression of democratic politics whereby there is not one hegemonic discourse, dictating the terms of debate, but several discourses which offer alternative forms of truth and alternative identities. The use of the conversational genre can also be seen as part of this democratization process in two respects: firstly, as expert knowledge is not mediated by journalists but by two experts, it is as if the viewers gain direct access to expert knowledge; secondly, the construction of knowledge partly in lay terms may both enhance viewers' understanding and also echo their own perspectives. However, the inequality between the different discourses works against this. The newsreader's introduction challenges the high risk discourse and favourises the anti-discourse through linguistic devices noted above. Moreover, through the simulation of a private conversation between Lester Brown and Bjørn Lomborg, the public are addressed as voyeurs or consumers of an entertaining show rather than as active citizen-participants in a debate. This can be seen in the light of the mediatization of politics, whereby politics has, to a large extent, become mediated and the boundary between the public and the private has become blurred. Mediatization involves an aesthetization of communication whereby the focus is on appearance and image and people become consumers of the visual spectacle: 'people, objects, events perform for the diffused audience through their involvement in a richly symbolic world of spectacle' (Abercrombie and Longhurst, 1998: 88). 
The implications of the above discursive practices can be explored further through analysis of the reception of the text by audiences. Reception analysis is a way of investigating how people respond to being confronted with rival scientific claims about risks rather than with uncontested scientific knowledge. How they do so provides insight into the implications of the mediatized contestation of expert knowledge for democratic politics.

\section{Audience Discourse}

Many respondents drew on the anti-discourse, appropriating it in different ways. And many audience members accepted the principle of epistemic doubt at the core of the antidiscourse. They used BL's arguments in order to claim that the risks were exaggerated, as in the following case:

Interviewer: Og hvad tænkte I mens I så det her indslag?

Martin: (2) Jah, hvad tænkte vi. (2)

Katrine: Ja, altså jeg, jeg, jeg, jeg tænkte nok første gang da jeg så det, at øh, jamen altså jeg sy, jeg synes heller ikke at, at, at de katastrofer og, og de ting som, som de gør så negative, er så negativt. Som, som det nogen gange bliver gjort til, vel. Fordi der er nogen ting vi, vi bare ikke kan hamle op imod. Og $\varnothing \varnothing \mathrm{h}$, vi har en skovbrand her, vi har en skovbrand der, ikke. Men, men $\varnothing \emptyset \mathrm{h}$, men vi har jo, vi har jo stadigvæk, man har jo sagt i mange år at, at nu skal du passe på, på træerne, for vi har, ikke, vi bruger for meget papir, øh det går ud over vores skove(ne), men vi har jo stadigvæk $\emptyset \mathrm{h}$ (1) plantet nye. Øh, jeg tror ikke det der, det er, det er så sort. Som de nogengange gør det til.

Interviewer: Nej (4) Hvor, hvor optagede er I af sådan et, et problem som det de diskuterer? Hvor vigtigt synes I det er? (2)

Martin: Jordens miljø? Synes jeg er meget vigtigt. =

Katrine: $=\mathrm{Mm}$

Martin: Men det vi sna, det, det der v, фh, altså jeg synes egentlig at, at den, det indslag det er jo $\varnothing \mathrm{hm}$, giver jo et, et glimrende $\varnothing \varnothing \mathrm{h}$, indblik i at (2) $\varnothing \mathrm{h}$ information n $\varnothing \mathrm{dvendigvis} \mathrm{ikke} \varnothing \mathrm{h}$, altså information (.) fra en eller anden (.) institut eller en eller anden forsker ikke nødvendigvis er fyldestg $\varnothing$ rende og ikke nødvendigvis er, er den r, den, den evige sandhed. Men at andre, $\varnothing$ h, ligeså dygtige eksperter ud i, i det samme emne, ka' ha' en helt anden holdning og indfaldsvinkel og øh konklusion på, om jeg så må sige, de samme statistikker. $\emptyset \emptyset h$, og der (1) mener jeg jo nok at meget af den information vi fär idag $\phi$ hh, er (.) meget manipuleret, $\phi \phi h$, og bliver brugt $\phi \phi h$ bevidst $\phi h i$ en eller anden $\phi \phi h s$, interesser eller en eller anden organisations interesser.

Katrine: $\mathrm{Mm}$

Martin: $\emptyset \emptyset \mathrm{h}$, hvis jordens $\varnothing \varnothing \mathrm{h}$ (3) miljø var (1) upåklageligt, så ville øh World Watch Institute have et problem med $\varnothing \mathrm{hm}$ (.) overleve sig selv. Så altså, information er jo $\varnothing \varnothing \mathrm{h}$ (.) godt nok, $\varnothing \varnothing \mathrm{h}$ og god at få, men den skal også være pålidelig. (4) Så (.) jeg synes der er mange (.) ffacetter i hele det der informationsræs (vi har).

[...]

Interviewer: Så udsendelsen giver ikke rigtig noget svar på (.)

Martin: Der er ikke noget svar.

Interviewer: $\mathrm{Mm}$

Katrine: Nej. 
Martin: Problemet er at, at hvis der kommer en og siger han har svaret, så er han meget utroværdig. For der er ikke noget svar. Men folk vil gerne ha' et svar, så de tror på ham der siger han har et svar. Sådan, sådan opfatter jeg det.

Interviewer: $\mathrm{Mm}$. Hvad gør man så når de begge to tror de har svaret i en udsendelse som

Martin: Og der (kan)

Interviewer: denne her?

Martin: Jamen altså $\varnothing \mathrm{h}$, jeg tror ikke $\varnothing \mathrm{h}$, at den danske forsker tror han har svaret. Jeg tror den danske forsker $\varnothing \mathrm{h}$ stiller sig op og $\varnothing \mathrm{h}$ (.) påviser at man kan så tvivl (1)

Katrine: $\mathrm{Mm}$

Martin: om at World Watch Institutes information er korrekt.

\section{Translation}

Interviewer: And what did you think when you watched this clip?

Martin: (2) Yeah, what did we think. (2)

Katrine: Yes, so I, I, I, I thought the first time I saw it that oh, well so I th, I don't think either that, that, that these catastrophes and, and the things which, which they do so negative, are so negative. Like they're sometimes made out to be. Because there are some things we, we just can't compete with. And oh we have a forest-fire here, we have a forest-fire there, no? But but oh oh but we do have, we do still have, it's been said for so many years that, that now you've got to look after, after the trees, because we have, no, we use too much paper, oh it harms our forests, but we still have oh (1) planted new ones. Oh, I don't think this here, it's, it's so black. As they sometimes make it out to be.

Interviewer: No (4) How, how concerned are you by that kind of a, a problem like the oen they are discussing? How important do you think it is? (2)

Martin: The earth's environment? I think it's very important =

Katrine: $=\mathrm{Mm}$

Martin: But what we talk, that, that there, w, oh, well I really think that, that the, this clip, it's ohm, it does give a, an excellent ooh insight into that (2) oh information isn't necessarily, oh, well information (.) from one or other (institute) or one or other researcher isn't necessarily complete and isn't necessarily the $r$, the, the eternal truth. But that other oh, just as clever experts out in, in the same area, can have a completely different attitude and angle and oh conclusion about what I can call the same statistics. Ooh and there (1) I do think that much of the information we get today ohh is (.) very manipulated ooh and is being used ooh consciously ooh consciously oh in someone or other ooh's interests or in some or other organisation's interests.

Katrine: $\mathrm{Mm}$

Martin: Ooh if the earth's ooh (3) environment was (1) unimpeachable, World Watch Institute would have a problem to ohm (.) So the information is ooh (.) good enough, ooh and good to get, but it should also be reliable. (4) So (.) I think there are many (.) ffacets in all this information race (we have).

$[\ldots]$

Interviewer: So the programme doesn't really give any answer to (.)

Martin: There is no answer.

Interviewer: $\mathrm{Mm}$

Katrine: No. 
Martin: The problem is that, that if someone comes and says he has the answer, so he's very untrustworthy. Because there is no answer. But people would like to have an answer, so they believe in the one who says that he has an answer. That's, that's how I see it.

Interviewer: $\mathrm{Mm}$. What do you do then when they both think they have the answer in a broadcast like

Martin: And which (can)

Interviewer: This one here?

Martin: Yeah well oh I don't think that the Danish researcher thinks he has the answer. I think the Danish researcher oh puts himself forward and oh (.) proves that you can doubt (1).

Here Katrine uses the principle of epistemic doubt at the core of the anti-discourse in order to legitimate a position of optimism. She backs up her doubt about the claims of the environmentalists by restating Lomborg's claim that new trees are being planted. Martin also aligns himself to BLs version of reality and supports this version partly through challenging LB's story. Martin uses rhetorical strategies in order to establish his and Lomborg's version as solid and objective and LB's as false and subjective. A key strategy used to undermine the truth value of Brown's claims is the reference to Brown's private interests or personal stake in his claims:

Ooh and there (1) I do think that much of the information we get today ohh is (.) very manipulated ooh and is being used ooh consciously ooh consciously oh in someone or other ooh's interests or in some or other organisation's interests. Ooh if the earth's ooh (3) environment was (1) unimpeachable, World Watch Institute would have a problem to ohm (.) So the information is ooh (.) good enough, ooh and good to get, but it should also be reliable. (4) So (.) I think there are many (.) ffacets in all this information race (we have).

Martin draws on two scientific discourses. One is a communication science discourse according to which there are five criteria for reliable information:

Martin: Man har jo, man har jo sådan rent, $\varnothing$ h, informations $\varnothing \mathrm{h}$ (1) teknisk har man jo 5 punkter som skal være opfyldt for at informationen er, er god nok.

Katrine: Mm. (2)

Interviewer: Hvad er det for 5 punkter?

Martin: Den skal være tilstede, til tiden, tilstrækkelig, troværdig og relevant. (2) Og hvis ikke den er det, såååh kan man ikke rigtig bruge den til noget. Hvis ikke alle 5 kriterier er opfyldt, såh øh, så kan man ikke rigtig bruge informationen til noget. $\mathrm{Og}$ det der er problemet med information, det er at sørge for at den er tilstede på det rigtige tidspunkt, $\varnothing \mathrm{h}$, hos de rig, hos de mennesker som skal bruge den på det tidspunkt, $\varnothing \mathrm{h},(1)$ og er relevant i det hele taget i den sammenhæng den bliver givet, ikke

\section{Translation}

Martin: You have, you have oh information oh information oh (1) technically you have 5 points which have to be satisfied for the information to be be good enough.

Katrine: Mm. (2)

Interviewer: What are the 5 points?

Martin: It should be in the right place, on time, sufficient, trustworthy and relevant (2) And if it is not, well one cannot really use it. If all the 5 criteria are not satisfied, 
well one cannot really use the information. And that is the problem with information, it is making sure it is in the right place at the right time oh, with the righ, with the people who need to use it at that time oh (1) and is relevant in general in the context it which it is given, right?

The interviewer asks Martin about the nature of the five points and, in reply, he lists them as scientific information. In this way, he positions himself as an 'expert' and invests his statements with an authority based on scientific knowledge rather life-experience. The other scientific discourse drawn on by Martin is a relativist discourse. He provides support for Lomborg's position by defining it as relativist: Yeah well oh I don't think that the Danish researcher thinks he has the answer. I think the Danish researcher oh puts himself forward and oh (.) proves that you can doubt (1). Thus by presenting Lomborg's position as a challenge to a scientific truth-claim rather than a scientific truthclaim in itself, Martin's allegiance to one particular version of the world - Lomborg's is united with his support for the position of epistemic doubt and his lack of faith in scientific knowledge ("there is no answer"). Scientific information is manipulated for group interests; scientific truth is non-existent. Together with sustained optimism, this scepticism towards scientific knowledge works to legitimate a lack of intervention in the environment and a lack of engagement in environmentalist politics/activism.

Several informants did not align themselves with either Lomborg's or Brown's positions but expressed confusion and dissatisfaction with their disagreement. They did not challenge scientific knowledge per se: unlike Martin and Katrine they do not express a lack of faith in science but a lack of faith in the two speakers because they air an argument which reveals scientific uncertainty, instead of presenting the truth about the world; the respondents position themselves as ordinary lay people who expect that scientists' role is to present certain knowledge:

Interviewer: det, jeg synes det er flot at der nogle mennesker der (er villige til at), der interesserer sig for hvordan det ser ud, ikke altså, (?)

Tina: Men det skal også helst være realistisk, altså (.). Sådan noget der, det siger ikke mig noget, altså påstand mod påstand, jamen det kræver så at man begynder at, at grave i sådan en sag og, og, det kan man jo ikke, vel, altså, jeg v, jeg synes egentlig altså øh, det virker forkert på en eller anden måde, at lægge sådan noget frem, altså det burde være en diskussion man tog inden det kom ud i, i medierne, ikke? (1) Det kan bare virke lidt pinligt at $ø$ h, det' sådan 'hvem ved mest', altså hvem har ret? Jeg synes det er pinligt, sådan noget.

Frederik: Ja.

Interviewer: Hvordan synes du så man skulle gøre? Eller hvem sku’, hvem sku’, ja hvordan skulle det foregå?

Tina: Ja, ved at sætte sig sammen, altså det er jo forskere, ikke. Altså sætte sig sammen og finde ud af, men hvordan ser det ud altså, (.) en af dem har jo taget fejl, ikke. Eller har ikke ret ihvertfald.

Tina: Det er ikke noget der er værd at spekulere over, når $\emptyset \mathrm{h}$, du ikke ved hvordan, hvad realiteten er.

Frederik: Nej. (3)

Interviewer: Føler I at der er en eller anden sandhed om det her?

Tina: Ja selvfølgelig er der en sandhed, men, vi ved jo stadigvæk ikke, 'hvem har ret?'

Frederik: Ja. Det kan lige så godt være 
Tina: Fordi de lå så langt fra hinanden, ikke, altså det var jo virkelig 180 grader den ene havde drejet, ikke?

\section{Translation}

Interviewer: It, I think that it's great that there are some people who (are willing to), who are interested in how things are, don't you think, (?)

Tina: But it's all should be realistic, well (.). that sort of thing, it doesn't do anything for me, claim against claim, well it requires that you have to start to, to dig into that sort of subject and, and you can't, well, so, I, w, I think really so oh, it seems wrong in some or other way, to put forward that kind of thing well it should be a discussion one had before it came on the media, right? (1) It can just seem a little embarrassing that oh it "who knows most", so who's right? I think it's embarrassing, that kind of thing.

Frederik: Yes.

Interviewer: What do you think one should do? Or who should, who should, yes, how should it be done?

Tina: Yes, by sitting down together, they are researchers, aren't they? Sitting down together and finding out, how things are (.) one of them has made a mistake, hasn't he? Or isn't right anyway.

Tina's argumentation is constructed in opposition to the interviewer's position (a positive view of the discussion). She positions herself against the experts by critising their performance, but she does not question expert knowledge and experts per se. On the contrary, she criticises Lomborg and Brown for not behaving like experts - that is, for not producing certain knowledge. Thus she does not express a lack of faith in science as such but in the two scientists for not providing the end-product of science: truth about the world. She evaluates their talk not in terms of expert discourse but in terms of an everyday discourse according to which things should be "realistic". By drawing on an everyday discourse, she positions herself as a lay person who expects that scientists present certain knowledge.

Another couple also express dissatisfaction with the situation of uncertainty in relation to which speaker is right and they both take for granted that there is a definite answer/certain truth:

Interviewer: Hvad tænkte I mens I så det? (3)

Tonya: Jeg har set det før, altså.

Daniel: Jamen jeg, altså det, det der jo sker det er jo at $\emptyset \mathrm{h}$, den ældre amerikaner der kommer der han kommer jo med (2) med (.) egentlig det vi er, er blevet fyldt med (2) de sidste mange år. Og har fået at vide. Så kommer der sådan en fræk fyr (1) og siger (1) det passer ikke. Verden ser helt anderledes ud. (4) Og så sidder vi her, (du), og hvem skal vi tro på, og hvad

Tonya: Ja man giver sig til at spekulere på, hvem skal man nu tro på ikke, skal man tro på ham den gamle garvede der har undersøgt tingene i masser af år, eller (1) eller det er den unge der har ret, ikke. Og øh, er han for (2) populær i sin fremgangsmåde, den unge måske, eller sådan et eller andet, ikke altså fordi han har en helt anden fremtoning (det kan jeg da huske ihvertfald, fra) (?) Helt anderledes.

Daniel: Ja, han er også, han er også meget politisk i det ikke fordi der er jo nogen der vil sige (3) altså dem der siger miljøet skal nok klare sig selv, ikke, de vil sige der kan vi se. Det passer slet ikke. De har sagt det (mange gange) 
Tonya: Man kunne godt gribe sig selv i at tænke på at få lov at se de tal (.) de begge to sad og diskuterede. Dem ville jeg godt se. Og så prøve at regne på dem, altså. Og finde ud af (2) ja fordi det irriterer én lidt at man ikke rigtig ved [griner] hvem har ret, ikke?

Daniel: Det er jo også svært. Det er svært (?) Vi kan bare se sådan noget som øh (2) med olie, altså vi havde de to første kriser dér, der snakkede (vi) om at nu var der olie til de næste 20 år og så var det knagme slut. Man finder mere og mere olie og man finder ud af at bruge mindre og mindre olie. Ja nu har vi så sågar

Tonya: Ja det er rigtig nok.

Daniel: sådan at de måtte (.) bliver nødt til at (1) producere mindre olie for at holde priserne oppe. Så det vil sige $\varnothing \mathrm{h}$ der snakkede man jo dommedag omkring olie (branchen) og vi dør af kulde allesammen og jeg ved ikke hvad. Og det er altså (?)

\section{Translation}

Interviewer: What did you think while you watched it? (3)

Tonya: I've seen it before.

Daniel: Well I, what, what happened, was that (oh) the elderly American, he comes, he comes with (2) with (.) really what we've been filled with (2) the past many years. And have been told. So this cheeky guy (1) comes and says (1) it's not right. The world looks completely different (4) And here we sit, (you, and whom should we believe in, and what

Tonya: Yes it gives you something to speculate about, who should you believe in, should you believe in him, the old experienced one, who has researched things for many years or (1) or is it the young one who's right, well? Og oh is he too (2) popular in his approach, the young one maybe, or something like that, because he has a completely different appearance (I can remember that anyway from) (?).

Daniel: Yes, he is also, he is also very political, right? Because there are some who would say (3) that is, those who say the environment can manage itself, right? They will say, there we can see. It is not right. They have said that (many times).

Tonya: You can easily find yourself thinking about getting permission to see those figures (.) the two of them sat discussing. I'd like to see those. And try and work them out,. And find out if (2) yes because it irritates you that you don't really know [laugh] who is right, isn't that so?

Daniel: It is also hard. It is hard (?). We can just look at something like oh (2) oil, we had the first two crises there, then (we) talked about how there was oil for the next 20 years and then it was bloody finished. One finds more and more oil and one finds out how to use less and less oil. Yes now we have even

Tonya: Yes that's right enough.

Daniel: so that they had to (.) have to (1) produce less oil to keep the prices up. So that means oh they talked about doomsday about (the) oil (branch) and that we'd all die of cold and I don't know what. And there's actually(?)

Like Tina, Daniel and Tonya present themselves as equals to the speakers rather than viewing them as greater authorities. They describe them in informal terms: Brown as the older American and "him, the old experienced one", and Lomborg as the "cheeky guy" and "the young one". In addition, they position themselves as critics who challenge the so-called experts: You can easily find yourself thinking about getting permission to see those figures (.) the two of them sat discussing. I'd like to see those. And try and work them out. And find out if (2) yes because it irritates you that you don't really know 
[laugh] who is right, isn't that so? In order to cast light on people's irritation at not being presented with certain knowledge, we can draw on Giddens's theory about trust in expert systems: he argues that despite the loss of faith in science, trust in experts and mediated knowledge works as a strategy that prevents people's feeling great anxiety because of uncertainty and the unknowability of risks - that we cannot precisely identify the sources of risk or undertake a course of action that we know with certainty will solve the problems (Giddens 1990).

\section{Conclusion}

Analysis of media and audience discourse indicates the dominance of the principle of epistemic doubt, an important component of the anti-discourse of low environmental risk. One group of viewers expressed a scepticism towards scientific knowledge per se whereas another group expressed a scepticism towards the speakers' knowledge as their knowledge is revealed as truth-claims which can be challenged rather than as definite facts. The first group's expressed lack of belief legitimated acceptance of Bjørn Lomborg's position of optimism about the environment. In accepting the terms of the anti-discourse, they did not recognise that Lomborg also constructed truth-claims and presented himself as an authority. His knowledge-claims were accepted as 'commonsense'. In contrast, in the case of the second group, their lack of belief supported a rejection of both positions, while their view that experts ought to provide the facts prevented them from formulating their own evaluation of environmental risk.

The question is whether these two forms of scepticism entail an opening-up of the debate to critical reflection on existing social arrangements (based on 'social rationality') or whether it entails a populist rejection of expert authority but no reasoned judgement. According to the view of democratic politics taken in this article, a populist questioning of experts' authority in itself cannot be understood as democratizing. Democratic politics needs to contain three main features: it requires public debate between a range of different discourses, representing competing understandings of the social world; it involves giving people the resources to take a critical, evaluative stance in relation to the competing claims about existing social arrangements and suggestions for courses of action; and it demands a public sphere in which the views of different social actors, including both experts and non-experts, are expressed and taken into account in decision-making processes.

None of these criteria was met in the present case. While two competing discourses the environmental discourse of high risk and the anti-discourse of low environmental risk - were articulated in media discourse, they were not given equal treatment. The favouring of the anti-discourse in the newsreader's and reporter's text and the way in which, throughout the whole broadcast, the anti-discourse drew on a conversational genre in which Bjørn Lomborg was positioned as both expert and ordinary person, worked towards populist rejection of the expert knowledge of Lester Brown, the speaker who draws on the environmental discourse of high risk and against a critical comparison between the two perspectives. The challenging of experts' arguments by citizens is crucial for democratic politics but only on the basis of qualified, competent critique and not a populist rejection of all expert authority.

Analysis of the media text indicated a link between populism and the mix of expert, institutional discourses and everyday, consumer discourses which simulate face-to-face, interpersonal communication. In this article, I discussed this briefly in terms of the æstheticization of communication whereby audiences are positioned as consumers of the 
visual spectacle rather than citizens. The link between populism and the mix of public and private discourses has also been identified in other research on Danish news programmes (Hjarvard 1999). A crucial question is whether institutional practices in the media can be transformed so that they produce a form of media discourse which supports reflexive democratic debate rather than a populist rejection of all expert authority in the name of 'the people'. To go further towards answering this question requires further research not only on media and audience discourse but on production processes in media institutions.

\section{Notes}

1. This paper was presented to the 14th Nordic Conference for Media and Communication Research, Workshop on the Sociology and Aesthetics of the News, Kungälv, den 14.-17. August 1999. It draws on the article "Nærvær på afstand? Den medierede kommunikation af ekspertviden i nyhederne" published in H. Christrup (1999) (editor), Narvarskommunikation. Frederiksberg: Roskilde University Press and on the conference paper, Chouliaraki, L. and Phillips, L. (1999) 'Dialogue and Reflexivity: Mediating Expert Knowledge', 'Working with Dialogue' Conference, 8-10 April, Birmingham University.

2. The study forms part of larger-scale research on discourses about ecological risks and political action across key social domains: public information material, media coverage and 33 interviews with media audiences (see, for example, Phillips 2000).

3. Pellizzoni (1996) distinguishes in an insightful way between approaches (such as Beck's) which attribute the social definition of environmental problems to their intrinsic nature and to knowledge, approaches which attribute the social definition of environmental problems to their intrinsic nature and to power, approaches which stress the role of the cultural dimension and knowledge and approaches which stress culture and power.

4. This perspective is positioned between, on the one hand, poststructuralist discourse theory which identifies abstract discourses circulating in society or in a specific social field and, on the other hand, forms of discourse analysis (heavily influenced by conversation analysis and ethnomethodology) which concentrate on how social organisation is accomplished through talk-in-interaction. At its extreme, discourse theory tends to reify discourses, viewing the individual language user as a mere epiphenomenon of discourse, while the tendency, at the other extreme, is to neglect that the specific discursive resources to which people have access delimit what it is possible for them to say (Phillips 2000).

\section{References}

Abercrombie, N. \& Longhurst, B. (1998) Audiences. London: Sage.

Alexander, J. (1996) Critical Reflections on 'Reflexive Modernization'. Theory, Culture and Society, 13(4): 133-138.

Anderson, A. (1994) Media, Culture and the Environment. London: UCL Press.

Beck, U. (1992) The Risk Society. London: Sage.

Beck, U. (1995) Ecological Enlightenment: Essays on the Politics of the Risk Society. New Jersey: Humanities Press.

Beck, U. (1996) Risk Society and the Provident State. in S. Lash, B. Szerszynski \& B. Wynne (eds.) Risk, Environment and Modernity: Towards a New Ecology. London: Sage.

Beck, U. (1997) The Reinvention of Politics. London: Routledge.

Beck, U., Giddens A. \& Lash, S. (1994) Reflexive Modernization: Politics, Tradition and Aesthetics in the Modern Social Order. Cambridge: Polity.

Bondebjerg, I. (1996) Public discourse/private fascination: hybridization in 'true-life-story' genres', Media, Culture \& Society, 18(1): 27-45.

Chouliaraki, L. (1999) Media Discourse and National Identity: Death and Myth in a News Broadcast, in R. Wodak (red.) Nationalisms and Globalization. Vienna: Passager Verlag.

Chouliaraki, L. \& Phillips, L. (1999) Dialogue and Reflexivity: Mediating Expert Knowledge, Annual Conference of the International Association for Dialogue Analysis, Working with Dialogue, 8-10 April, Birmingham University, UK.

Cottle, S. (1998) Ulrich Beck, "Risk Society" and the Media: A Catastrophic View? European Journal of Communication, 13(1): 5-32. 
Eder, K. (1996) The Institutionalisation of Environmentalism: Ecological Discourse and the Second Transformation of the Public Sphere, in S. Lash, B. Szerszynski \& B. Wynne (eds.) Risk, Environment and Modernity: Towards a New Ecology. London: Sage.

Fairclough, N. (1992) Discourse and Social Change. Cambridge: Polity Press.

Fairclough, N. (1995a) Critical Discourse Analysis. London: Sage.

Fairclough, N. (1995b) Media Discourse. London: Edward Arnold.

Featherstone, M. (1991) Consumer Culture and Postmodernism. London: Sage.

Foucault, M. (1972) The Archaeology of Knowledge. London: Routledge.

Giddens, A. (1990) The Consequences of Modernity. Cambridge: Polity.

Giddens, A. (1991) Modernity and Self-Identity. Cambridge: Polity.

Habermas, J. (1989) The Structural Transformation of the Public Sphere: An Inquiry into a Category of Bourgeois Society. Cambridge, MA.: MIT Press.

Habermas, J. (1994) Forord til nyudgivelsen af Strukturwandel der Öffentlichkeit, Mediekultur 22: 53-64.

Hannigan, J. (1995) Environmental Sociology: A Social Constructionist Perspective. London: Routledge.

Hjarvard, S. (1997) Simulerede samtaler - om forholdet mellem interpersonel kommunikation and medieformidlet kommunikation. MedieKultur 26: 5-17.

Hjarvard, S. (1999) TV-Nyheder i konkurrence. Frederiksberg: Samfundslitteratur.

Horton, D. \& Wohl, R. (1956) Mass Communication and Para-social Interaction: Observation on Intimacy at a Distance. Psychiatry, 19: 215-219.

Horton, D. \& Wohl, R. (1997) Massekommunikation and parasocial interaktion: et indlæg om intimitet på afstand. MedieKultur, 26: 27-39.

Jørgensen, M.W. \& Phillips, L. (1999) Diskursanalyse som Teori and Metode [Discourse Analysis as Theory and Method]. Frederiksberg: Samfundslitteratur/Roskilde University Press.

Pellizzoni, L. (1999). Reflexive Modernization and Beyond: Knowledge and Value in the politics of Environment and Technology. Theory, Culture and Society. 16(4): 99-125.

Phillips, L. (1999a) Media Discourse and the Danish Monarchy: Reconciling Egalitarianism and Royalism. Media, Culture and Society, 21(2): 221-245.

Phillips, L. (1999b) Nærvær på afstand? Den medierede kommunikation af ekspertviden, in H. Christrup (ed.) Narvarskommunikation. Frederiksberg: Roskilde University Press.

Phillips, L. (2000) Mediated Communication and the Privatization of Public Problems: Discourse on Ecological Risks and Political Action. European Journal of Communication, 15(2): 171-207.

Potter, J. (1996) Representing Reality: Discourse, Rhetoric and Social Construction. London: Sage.

Potter, Jonathan \& Wetherell, Margaret (1987) Discourse and Social Psychology: Beyond Attitudes and Behaviour. London: Sage.

Schrøder, K. \& Phillips, L. (1999) Mediatized Politics: Political Discourses and the Media in Contemporary Danish Democracy. A Project Outline. Nordicom Review 20(2) and Nordicom Information 21(4).

Silverstone, R. (1994) Television and Everyday Life. London: Routledge.

Thompson, J. (1995) The Media and Modernity: A Social Theory of the Media. Cambridge: Polity.

Wetherell, M. \& Potter, J. (1992) Mapping the Language of Racism. Hemel Hempstead: Harvester Wheatsheaf. 
